\section{雑誌『通動界』（第1 次）誈事索引目録の作暼につ} $\omega \tau$

$$
\text { 上智大学 伊 東 明 }
$$

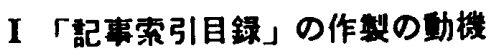

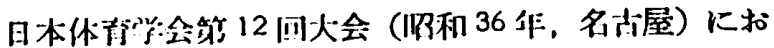

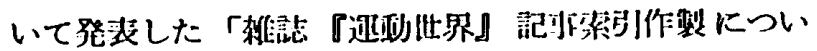

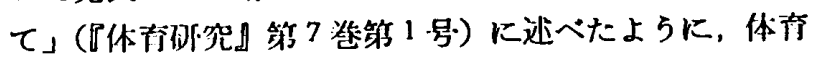

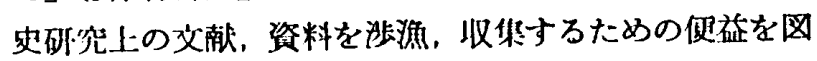
ろらとした。

\section{II『正動界』(第 1 次) 刊行目錄}

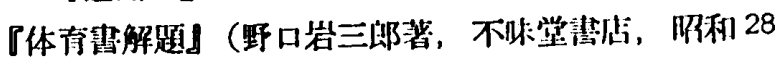

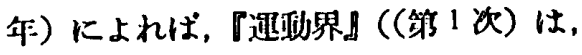

\section{うんどうかい}

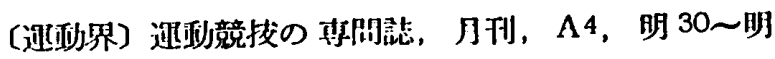

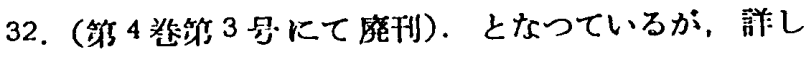
い刊行年月は，明治30年 (1897) 7 月から明治 33 作 (1900) 3 月までの 2 胙9 9 力であり，籍 4 管第了号, 通焱33号まで発刊されている。

\section{III 『運動界』(第 1 次) の所在目録}

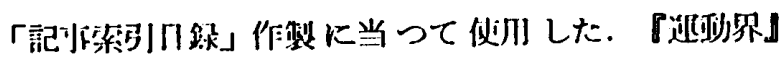

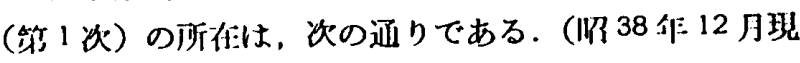
标

\begin{tabular}{|c|c|}
\hline 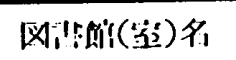 & 㥕 - 哭 数 \\
\hline 国立国会因暂䗆 & 筑 1 巻筑 1 号～第 4 炎筑了 \\
\hline
\end{tabular}

IV「道名索引」の項目の分類と排列

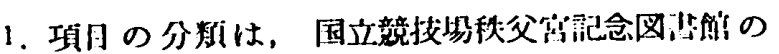

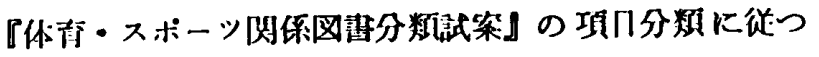
た.

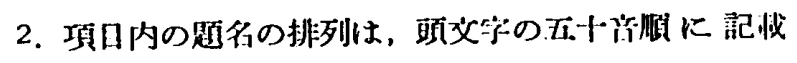
した.

\section{V 記事題名の記載の順席}

1. 記戊の期序を例示すれば火火火通りである.

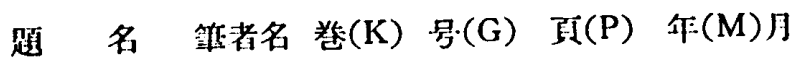
迅動と風紀 臨南生 $2011 \quad 1 \sim 2 \quad 31.11$

2. 発行作月の $\mathrm{M}$ は, 明治を示寸.

3. 旧测字，門仮名つかいは，できるかきり，当四筷 字, 新仮名つかいに改めた。

\section{VI『運嘞界』(第 1 次) の内容について}

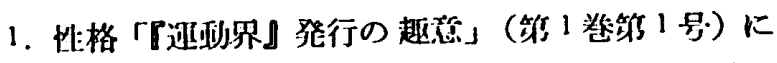

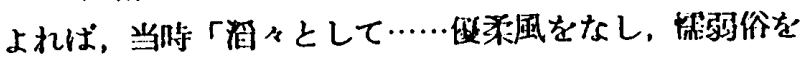

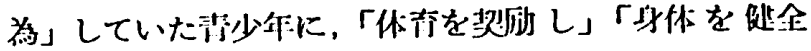

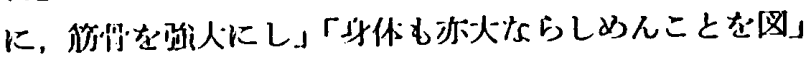
つて創刊された。

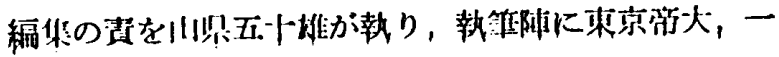

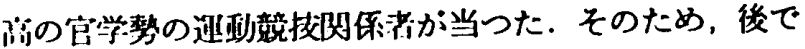

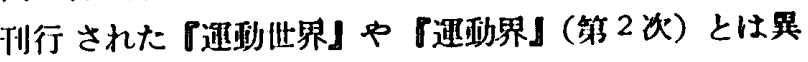
り，学校色の海い，啓望的な面が溞く現われている。

2. 刊行された時代

(1) スボーツが国绦的に普及しつつあつた.

『迅酹界』(籍1 次) 創刊の前の年, 明治 29 年 (1896) には，フテネで第1回オリンピック親技が阴倠され，こ れを埙機として，世界的にスポーツが音及し始め，創刊 の作には，ボストン・マランンが眀始され，スボーツ界 の国際交旅か濑く行なわれよ5とする気逨にあつた。

(2) わが园のスボーツ界は官学の全盛時代

東都の代表として，野球では一高，莛球では高師，高

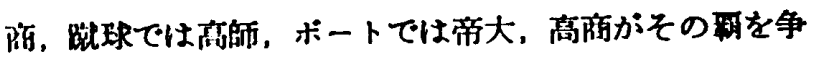

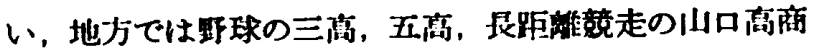

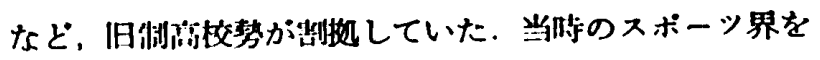
牛开つていたのは，全てこれ官学勢であつて，早，曼が 抬颛してスボーツ界に私学が朝を晿えるよらになつたの け，この雑誌が廃刊になつて以後のことであつた。

(3) 不渭外人チームとの交流狱命が行なっれるよ5に なつた.

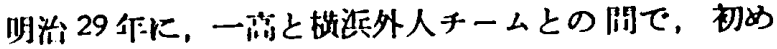
て野湬の試令が掠たれ，明治31 作 (1898) には，水府

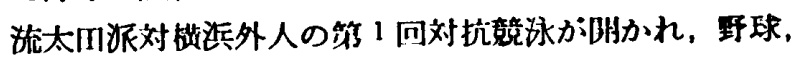

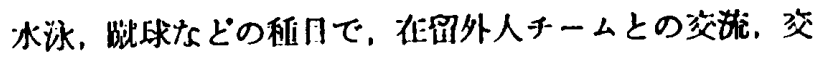
微試命が行なわれ，技術の進步に大きく项献した。

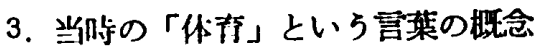

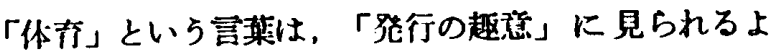
5に，破に地䦌一般に使われていたよらに思われる。そ の恋味するところは，教育の内谷を智方，德青，体有の

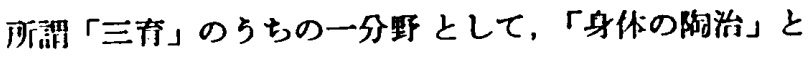

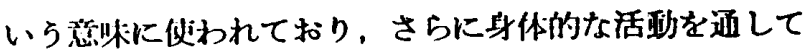

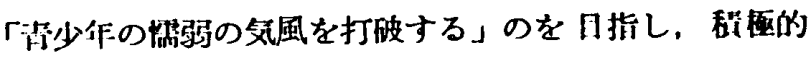

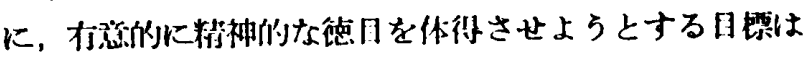
・劣えられていない。

\section{4. 䅦日夘にみた主な記訢の数}

洴艇が 86 で一番多く，次いて野球の 62，旅行，遠足

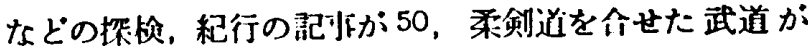

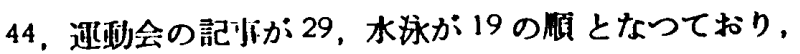

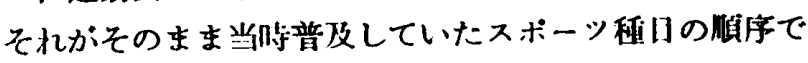
あろう。

\section{VII 结}

「迅政界】(第1 次) は，わが国スポーツ界の奻年期を 砄究一る上での好筑の资料の一つであり，先に阼製され

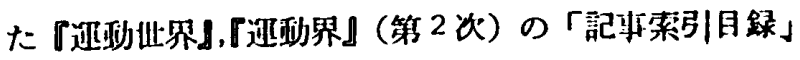
と併せ活用されることを望さ， 